\title{
Presence of Leptospire spp. in urban bats from Sincelejo, Sucre, Colombia
}

\author{
Robin Jesús Victoria ${ }^{1}$, Lilia Judith Iriarte ${ }^{2}$, Alcides C. Sampedro ${ }^{1^{\star}}$ \\ ${ }^{1}$ Research Group on Tropical Biodiversity, University of Sucre, Colombia: \\ ${ }^{2}$ Biomedical Research Group, University of Sucre, Colombia.
}

\author{
Correspondence: \\ Alcides C. Sampedro Marín, \\ Grupo de Investigación en Biodiversidad Tropical, Universidad de Sucre, Carrera 28 \\ No. 5-267. Sincelejo-Sucre. Colombia. Cellular: 3106022262.
}

\begin{abstract}
Leptospirosis is one of the most frequent zoonoses worldwide and occurs in tropical, subtropical and temperate areas. The genus Leptospira comprises saprophytic and pathogenic species. The latter isolated from several animals that serve as reservoirs and carriers. The presence of bats in urban areas has increased for various reasons, profusion of plants, lack of predators, presence of luminaries, which has increased the chances of contact between bats, humans and/or pets. The aim of this work was to investigate the presence of pathogenic Leptospira in bats captured in the city of Sincelejo, using the molecular PCR technique. Mist nets were used to capture the bats and these were sacrificed using ether to obtain samples of renal tissue. A fragment of the LipL32 gene was amplified by PCR technique. We identified three families of bats amongst our sample and $26 \%$ of them presented pathogenic Leptospira DNA. This represents a great risk to the community in this region.
\end{abstract}

Keywords: Keywords: Chiroptera, bats, leptospires, DNA, zoonoses, infection.

Introduction

Leptospirosis is recognized as a zoonotic disease of worldwide distribution ${ }^{1}$ present more frequently in tropical countries. The disease is caused by spirochetes of the genus Leptospira, currently classified into two groups: the infectious group (subdivided as pathogens and intermediate pathogens) and the non-infectious group (nonpathogenic or saprophytic) ${ }^{2}$. The spirochetes are present in a large variety of mammals that act as carriers, for example cattle, pigs, goats, canines, marsupials and rodents ${ }^{3}$, which increases the probability of transmission of the disease to humans.

International Journal of PharmTech Research, 2018,11(3): 218-225

DOI: http://dx.doi.org/10.20902/IJPTR.2018.11303 
The numerous diseases associated with bats, such as rabies, leptospirosis, histoplasmosis, equine encephalitis, which can be transmitted to animals and humans ${ }^{4}$, are of great scientific interest. Bats can also cause considerable damage to the buildings where they live $e^{5}$, however, in urban environments bats have a positive impact because of their capacity to control insect pests ${ }^{6}$.

There is a varied collection of pathogenic species of Leptospira that have been identified in bats with different food habits, and specific variations in bacterial infection rates may indicate that some species of bats are more exposed to them ${ }^{7}$.

The Polymerase Chain Reaction (PCR) is a sensitive, specific and rapid technique that has been successfully applied in the detection of several microorganisms and viruses in a variety of samples, including sputum, cerebrospinal fluid, urine, feces, and several tissues ${ }^{8}$. It is a technique of greater specificity and sensitivity than serological tests ${ }^{9}$.

The most studied outer membrane lipoprotein in Leptospira is LipL32, highly immunogenic ${ }^{10}$ and most conserved among the pathogenic species, with more than $94 \%$ identity of the amino acid sequence among the main pathogenic species (L. interrogans, L. borgpetersenii, L. kirschneri, L. noguchii, L. santarosai, and $L$. (weilii) $^{11}$.

In the city of Sincelejo, capital of the department of Sucre, Colombia, some species of bats live in or near educational institutions and other human constructions ${ }^{6,12}$. For this reason in the present work, was used a molecular technique for the detection of Leptospira spp. in bats collected in these institutions. This would allow obtaining evidence to help clarify its incidence in the health of the community.

\section{Materials and Methods}

The investigation was done throughout a period of one and a half years, between May 2013 and November 2014. It was carried out in four schools in the urban area of the municipality of Sincelejo, located in the north of the country in the department of Sucre, Caribbean region of Colombia. The geographic coordinates of Sincelejo are $9^{\circ} 18^{\prime} \mathrm{N} ; 75^{\circ} 23^{\prime} \mathrm{O}$. It has a population of approximately 260,000 inhabitants ${ }^{13}$, maximum elevation of 260 masl $^{14}$ and an urban area of $281 \mathrm{Km}^{2}$ with characteristics of tropical dry forest ${ }^{15}$.

Educational institutions where the presence of bats was known were selected. The main resting place was the attic (space between the ceiling, made of etherboard or wood, and the roof of the building, commonly of eternit). To capture the bats, nylon fog nets of $12 \mathrm{~m}$ long x $2.5 \mathrm{~m}$ high with a $36 \mathrm{~mm}^{2}$ eye, were placed approximately one meter from the access points to the shelters. Nets were in place before 18:00, reviewed every 30 minutes and removed at 23:00.

The taxonomical identification was carried out by means of a taxonomic key ${ }^{16}$. The Specific Importance Index (SII) was determined by adding the capture frequencies (CF) and the appearance of the bats in the shelters (RF), thus:

$\mathrm{SII}=\mathrm{CF}+\mathrm{RF}$

where SII: Specific Importance Index

$\mathrm{CF}: \mathrm{ni} / \mathrm{N} \quad$ ni: number of individuals captured of the $\mathrm{i}$-th species

$\mathrm{N}$ : total number of individuals captured

RF: ri/R ri: number of shelters in which each species was captured

R: number of shelters sampled

The value of the index ranges between 0 and 2 .

In accordance with animal welfare standards, bats were numbed with ether and stored at $-80^{\circ} \mathrm{C}$ in a freezer. The sex and reproductive condition were verified for both males and females ${ }^{6}$ and each animal was weighed using a Traveler digital scale with an error of $\pm 0.1 \mathrm{~g}$. The relative age (juvenile, adults and old), was 
determined by observation of the ossification state of the articular cartilage between the metacarpal bone and the phalanx of the third finger ${ }^{17}$. Subsequently, samples of renal tissue were taken and preserved at $-80^{\circ} \mathrm{C}$ until DNA extraction.

The extraction of DNA was carried out by the method of high concentration of salts, similar to that proposed by the Animal Genomics Laboratory ${ }^{18}$, with the following modifications: for the degradation of the protein fraction associated with DNA, $15 \mu \mathrm{L}$ of proteinase $\mathrm{K}$ was added instead of $35 \mu \mathrm{L}$ followed by incubation in a digital dry block for 3 instead of 5 hours for its activation. To improve the precipitation of the protein fraction, $150 \mu \mathrm{L}$ of $\mathrm{NaCl}(6 \mathrm{M})$ was added instead of $166.7 \mu \mathrm{L}$. To precipitate the DNA, $500 \mu \mathrm{L}$ of cold absolute ethanol was added to the supernatant (previous step) instead of $800 \mu \mathrm{L}$. The DNA samples were stored at $-20{ }^{\circ} \mathrm{C}$ until their later use. DNA quantification was performed with a spectrophotometer (NanoDrop 2000, Thermo Scientific) using $2 \mu \mathrm{L}$ of the DNA sample.

A conventional PCR was performed with the LipL32 / 270 forward primers (5'- CGC TGA AAT GGG AGT TCG TAT GAT T-3') and LipL32 / 692 reverse (5'- CCA ACA GAT GCA ACG AAA GAT CCT TT-3' ), described by Levett et al ${ }^{19}$, which amplify a 423 bp DNA fragment of the gene encoding the LipL32 lipoprotein. The PCR reactions were performed in a total volume of $35 \mu \mathrm{L}$, of which $2 \mu \mathrm{L}$ corresponded to bat kidney DNA and the rest of the volume to the PCR cocktail, prepared with the following conditions: 1X PCR buffer, $3 \mathrm{mM} \mathrm{MgCl} 2,1 \mathrm{U}$ Taq DNA polymerase / $\mu \mathrm{L}, 0.25 \mathrm{mM}$ dNTPs (Invitrogen ${ }^{\mathrm{TM}}$, Life Technologies), 0.1 $\mu \mathrm{M}$ LipL32 / 270, $0.1 \mu \mathrm{M}$ LipL32 / 692. The PCR was performed with the following thermal profile: an initial denaturation phase at $94^{\circ} \mathrm{C}$ for 4 minutes, followed by 35 cycles of denaturation at $94^{\circ} \mathrm{C}$ for 45 seconds, alignment at $55^{\circ} \mathrm{C}$ for 1 minute, extension at $72^{\circ} \mathrm{C}$ for 35 minutes, and a final extension to $72^{\circ} \mathrm{C}$ for 6 minutes in a Veriti thermocycler (Applied Biosystems). A positive and a negative control consisting of DNA from Leptospira grippotyphosa serovar and Leptospira biflexa serovar Patoc cultures, were respectively amplified.

The PCR products were visualized through agarose gel (1.5\%) electrophoresis at 80 volts for 50 minutes, in a $0.5 \mathrm{X}$ TBE buffer solution, previously stained with fluorescent intercalating agent (Gel Star, Lonza). The size of the amplifications was estimated with a molecular weight marker of $100 \mathrm{bp}$ (Invitrogen ${ }^{\mathrm{TM}}$, Life Technologies), and its visualization was carried out by means of a QUANTUM-ST4 documentary photo.

To assess the possible association between the prevalence of infection by Leptospira spp. pathogen and the variables species, reproductive status, relative age and sex, Single Classification Contingency Tables (X2) were used, through the Infostat software, student version

\section{Results}

The bat sample of the present study consisted of 185 individuals from four species, included in three families: Phyllostomidae (Loncophylla fornicata), Molossidae (Molosssu molossus and Eumops nanus) and Vespertilionidae (Myotis nigricans)

The most important species for its high proportion in the total number of individuals and its presence in the largest number of shelters was Lonchophylla fornicata (Table 1), the rest appear with very low values of the calculated importance index.

Table 1. Specific Importance Index (SII). Lf: Lonchophylla fornicata; En: Eumops nanus; Mm: Molossus molossus; Mn: Myotis nigricans; CF: proportion of individuals of each species in relation to the total number of individuals captured; Ri: number of shelters in which each species was captured; RF: proportion of refuges in which each species was captured in relation to the total number of refuges sampled.

\begin{tabular}{|c|c|c|c|c|c|}
\hline Species & ni & CF & Ri & RF & SII \\
\hline $\mathbf{L ~ f ~}$ & 133 & 0,718 & 8 & 0,8 & 1,52 \\
\hline $\mathbf{E}$ n & 19 & 0,102 & 3 & 0,3 & 0,40 \\
\hline $\mathbf{M} \mathbf{~ m}$ & 31 & 0,167 & 2 & 0,2 & 0,37 \\
\hline $\mathbf{M} \mathbf{n}$ & 2 & 0,01 & 1 & 0,1 & 0,11 \\
\hline
\end{tabular}


Most species share refuge in different proportions. However, Lonchophyla fornicata appears alone in five shelters and Molossus molossus in one of them (Fig. 1).

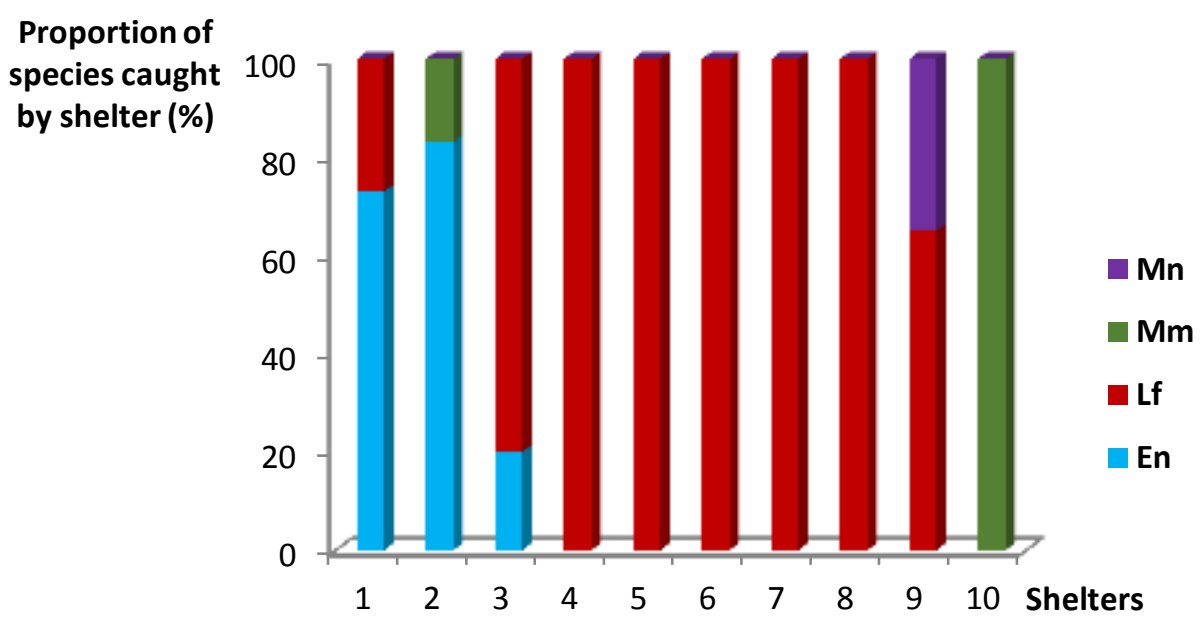

Fig. 1. Relative frequency of species captured by shelters. Mn: Myotis nigricans; Mm: Molossus molossus; Lf: Lonchophylla fornicata; En: Eumops nanus.

The overall prevalence of infection with Leptospira spp. in the bats was $26 \%$.. L. fornicata appears with the bacteria in all the shelters where it was captured alone (4 to 8 ) or in coexistence with E. nanus ( 1 and 3 ), which is the other infected species. Leptospira is not present in refuge 9 where L. fornicata lives with $M$. nigricans, which was not infected either. Fig. 2 shows the presence of amplified Leptospira spp DNA in some samples.

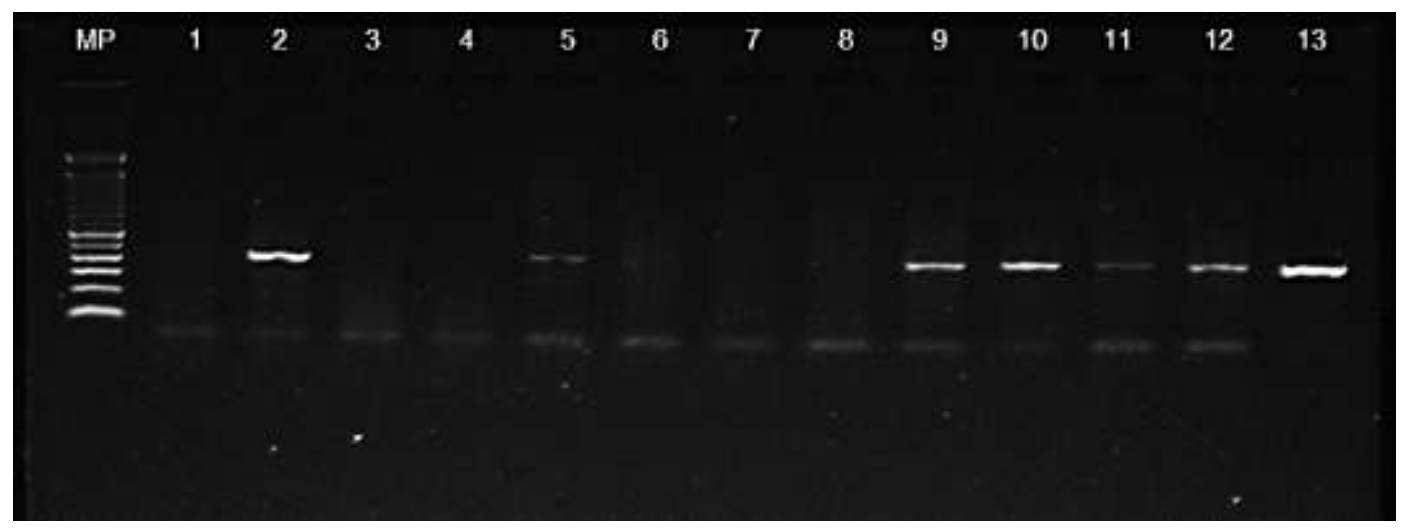

Fig. 2. PCR products amplified with the LipL32 primers in L. fornicate and $E$. nanus (MP: molecular weight marker, lane 1: negative control; lanes 2, 5, 9, 10, 11, 12: fragment of $423 \mathrm{bp}$ lipL32 amplified from DNA samples; 13: positive control).

Leptospira DNA was detected in only two of the species sampled (Lonchophyla fornicata and Eumops nanus) (Table 2). Of these infected individuals, $77.1 \%$ were male and $22.9 \%$ female. The reproductive status was relatively balanced between immature $(54.1 \%)$ and mature $(45.9 \%)$ individuals. Regarding relative age, it was found that $20.8 \%$ of the individuals, regardless of sex, were juveniles, $66.7 \%$ and $12.5 \%$ adults and old respectively.

Table 2 shows that there are no significant differences in the frequency of Leptospira spp. between $E$. nanus and L. fornicata. No statistical difference was obtained between the sexes nor the relative ages for any of these species. For L. fornicate, the prevalence of infection in reproductively active individuals, regardless of 
sex, is significantly higher than in those not active. The comparison is not possible in E. nanus because no infected females were collected.

Table 2. Association of the infection by Leptospira spp with species, relative age, reproductive status and sex, in bats captured in educational institutions of Sincelejo, Sucre. Lf: Lonchophylla fornicata; En:

Eumops nanus.

\begin{tabular}{|c|c|c|c|c|c|c|}
\hline Variable & Category & $\begin{array}{l}\mathbf{N}^{\circ} \text {. captured } \\
\text { individuals }\end{array}$ & $\begin{array}{l}\mathbf{N}^{\circ} \text {. positive } \\
\text { individuals }\end{array}$ & $\begin{array}{c}\text { Prevalence } \\
\text { of infection } \\
\text { by } \\
\text { Leptospira } \\
\text { spp. (\%) } \\
\end{array}$ & $\begin{array}{c}\text { Statistical } \\
\text { test }\end{array}$ & $\mathbf{p}$ \\
\hline \multirow[t]{5}{*}{ Species } & & & & & $x^{2}=2,16$ & $>0,05$ \\
\hline & E. nanus & 18 & 3 & 16,7 & & \\
\hline & L. fornicata & 133 & 45 & 33,8 & & \\
\hline & M. molossus & 31 & 0 & 0 & & \\
\hline & M. nigricans & 2 & 0 & 0 & & \\
\hline \multirow[t]{2}{*}{ Relative age } & & & & & $x^{2}=0,42$ & $>0,05$ \\
\hline & Juvenile & 3 & 1 & 33,3 & & \\
\hline \multirow[t]{4}{*}{ In } & Adult & 12 & 2 & 17,7 & & \\
\hline & Old & 3 & 0 & 0 & & \\
\hline & & & & & $x^{2}=2,93$ & $>0,05$ \\
\hline & Juvenile & 34 & 9 & 26,5 & & \\
\hline \multirow[t]{2}{*}{ Lf } & Adult & 75 & 30 & 40 & & \\
\hline & Old & 24 & 6 & 25 & & \\
\hline \multirow[t]{2}{*}{$\begin{array}{l}\text { Reproductive } \\
\text { status }\end{array}$} & & & & & $x^{2}=0,06$ & $>0,05$ \\
\hline & Immature & 5 & 1 & 20 & & \\
\hline \multirow[t]{3}{*}{ En } & Mature & 13 & 2 & 15,4 & & \\
\hline & & & & & $x^{2}=5,21$ & $<0,05$ \\
\hline & Immature & 91 & 25 & 27,5 & & \\
\hline Lf & Mature & 42 & 20 & 47,6 & & \\
\hline \multicolumn{7}{|l|}{ Sex } \\
\hline & Male & 12 & 3 & 25 & & \\
\hline \multirow[t]{3}{*}{ In } & Female & 6 & 0 & 0 & & \\
\hline & & & & & $x^{2}=2,68$ & $>0,05$ \\
\hline & Male & 88 & 34 & 38,6 & & \\
\hline Lf & Female & 45 & 11 & 24,4 & & \\
\hline
\end{tabular}

\section{Discussion}

The role played by bats in the epidemiological chain of Leptospira is still not completely clear. The prevalence of Leptospira spp. in bats of the urban area of the municipality of Sincelejo demonstrates that these animals are a reservoir of pathogenic species of Leptospira in this region. Studies carried out in southern Tanzania $^{20}$ and northeastern Peru ${ }^{21}$ suggest that bats may be potential reservoirs in the transmission of Leptospira to humans in these regions. These investigations report a prevalence of kidney infection of $27.3 \%$ 
and $35 \%$ respectively, such as that found in the present study, perhaps because in these countries there is a similar climate.

In contrast, Matthias et $a l^{22}$ reported a prevalence of $3.4 \%$ in insectivorous bats in the city of Iquitos, a percentage very similar to that described in Brazil $^{23}$, which was $2 \%$. This suggests that bats are not important in the transmission of leptospirosis in this area and possibly in other urban areas with similar characteristics, but could play a role in the maintenance of Leptospira in the environment. The same authors ${ }^{22}$ had identified $L$. interrogans serovar icterohaemorrhagiae in kidneys of bats from Peru, a common variety in rats.

In agreement, Dietrich et $a l^{24}$ point out that the predominance of Leptospira and the seroprevalence in bat populations vary according to the species and the place. They found that bats are infected by at least four species of pathogenic Leptospira (L. interrogans, L. borgpetersenii, L. kirschneri, L. fainei), especially in tropical regions with high richness of bat species .

In the present investigation, L. fornicata (nectarivorous) presented the highest prevalence, which may be in accordance with its higher Importance Index. It is possible that in a larger sample, with greater species richness and number of individuals, greater prevalence is evidenced. In the city of Sincelejo 12 species of bats ${ }^{12}$ were reported, among which Lonchophyla fornicata (formerly L. thomasi) and Molossus molossus, were the most abundant, especially in low ceilings of different building types, including educational institutions. Bats in this region seem to enjoy good climatic and food conditions, so it would not be uncommon for other species to exist, as in the rural area of the department ${ }^{12}$. In addition, the bat species where Lepstospira spp was detected seem to be in a good state of growth, according to the results related to the distribution of ages ${ }^{25}$, which is another reason to alert the health authorities of this municipality.

In some species, such as obligate insectivores ${ }^{7}$ Leptospira only appears occasionally. The lack of infection in Molossus molossus and Myotis nigricans, obligate insectivores, corroborates this notion, while Eumops nanus, with the same trophic specialty was not infested or presents Leptospira with very low prevalence.

The association of the infection with sex in L. fornicata (greater infection in active males), does not lead to any definitive conclusions, because there are no records of infection for this species and because other authors have found opposite differences to those obtained here for different species (greater infection in females) $)^{9}$.

Finally, since only Educational Institutions were sampled in this study,, which excludes a large percentage of buildings infested by bats in Sincelejo ${ }^{6}$, an even higher prevalence of Leptospira than that detected can be expected for the region and the number of bat species infested may indeed be greater.

\section{Conclusions}

The presence of Leptospira in bats of the municipality of Sincelejo and the possibility that it is present in other localities of the department of Sucre constitutes a risk factor, especially for local children, since the infection has been detected in school buildings.

The prevalence of Leptospira in Sincelejo could be higher than that obtained if other buildings are considered, because this would surely increase the species richness of bats and the sample number.

\section{Acknowledgments}

This research was possible due to financing by the University of Sucre and the Biomedical Research Group of this institution, which facilitated the molecular biology experiments. 


\section{References}

1. Levett, P. (2001). Leptospirosis. Clinical Microbiology Reviews, 14(2), 296-326. doi:10.1128/CMR.14.2.296-326.2001.

2. Romero-Vivas, C., \& Falconar, A. (2016). Leptospira spp. and human leptospirosis. Salud Uninorte, 32(1), 122-143. doi:10.14482/sun.32.1.8479.

3. Rojas, J., M. Céspedes. (2008). Desarrollo del PCR REP1 para diferenciar serovares de Leptospira sp y comparación con la prueba inmunológica MAT (ensayo microscópico de aglutinación). Rev. Per. Obst., 4, 72-78.

4. $\quad$ Bragg, S. L., Plikaytis, B., Perkins, B. A., Kaiser, R. M., Weyant, R. S., Spiegel, R. A., \& De Lose Reyes, J. O. (2000). Asymptomatic infection and risk factors for leptospirosis in Nicaragua. The American Journal of Tropical Medicine and Hygiene, 63(5-6), 249-254. doi:10.4269/ajtmh.2000.63.249.

5. $\quad$ Cleveland, C., Betke, M., Federico, P., Frank, J. D., Hallam, T. G., Horn, J., \& Kunz, T. H. (2006). Economic value of the pest control service provided by Brazilian free-tailed bats in south-central Texas. Ecology \& Environment, 4(5), 238-243. doi:10.1890/1540-9295(2006)004[0238:EVOTPC]2.0.CO;2.

6. Sampedro, A., Martínez, C., Otero, Y., Santos, L., Osorio, S., \& Mercado, A. (2008). Presencia del murciélago casero (Molossus molossus Pallas, 1776) en la ciudad de Sincelejo, departamento de Sucre, Colombia. Rev. Caldasia, 30(2), 495-503.

7. Muhldorfer, K. (2013). Bats and bacterial pathogens: a review. Zoonoses and Public Health, 60(1), 93103. doi:10.1111/j.1863-2378.2012.01536.x.

8. Almenteros, C., Arrieta, G., Máttar, S., Barguil, A., Tamayo, L., Padilla, T., \& Ríos, R. (2004). Seroprevalencia de leptospirosis porcina en el Departamento de Córdoba. Revista Colombiana de Ciencias Pecuarias, 17(2), 141-147.

9. Ramírez, N., Alegre, E., Ruiz, R., De Biasio, M., \& Bastiani, C. (2014). Detección de leptospiras patógenas en tejido renal de murciélagos de Corrientes, Argentina. Revista Veterinaria, 25, 16-20.

10. Malmstrom, J., Beck, M., Schmidt, A., Lange, V., Deutsch, E., \& Aebersold, R. (2009). Proteome-wide cellular protein concentrations of the human pathogen Leptospira interrogans. Rev. Nature, 460(7256), $762-765$.

11. Murray, G. (2013). The lipoprotein LipL32, an enigma of leptospiral biology. Veterinary Microbiology, 162(2-4), 305-314. doi:10.1016/j.vetmic.2012.11.005.

12. Sampedro, A., Martínez, C., De La Ossa, K., Otero, Y., Santos, L., Osorio, S., \& Mercado, A. (2007). Nuevos registros de especies de murciélagos para el departamento de Sucre y algunos datos sobre su ecología en esta región colombiana. Rev. Caldasia, 29(2), 355-362.

13. DANE. Informe de coyuntura económica regional. Convenio Interadministrativo No. 111 de abril de 2000. Fecha de consulta: 23 de septiembre de 2017. Disponible en: https://www.dane.gov.co/files/icer/2015/ICER_Sucre2015.pdf

14. Instituto Geográfico Agustín Codazzi (IGAC). Monografías del departamento de Sucre. Oficina de estudios geográficos. Bogotá. 1969. p. 54.

15. CARSUCRE. Plan de acción 2012-2015. Subregión Montes de María. Colombia. Fecha de consulta: 25 de febrero de 2017. Disponible en: http://unicesar.ambientalex.info/infoCT/PLAN.pdf.

16. Díaz, M., Solari, S., Aguirre, L., Aguiar, R., \& Bárquez, R. Clave de identificación de murciélagos de Sudamérica. Publicación especial $N^{\circ}$ 2, PCMA (Programa de Conservación de los Murciélagos de Argentina). 2016: 160. Fecha de consulta: 25 de marzo de 2017. Disponible en: http://www.academia.edu/30089461/Clave_de_los_Murcielagos_de_Sud_America.

17. Brunet, A., \& Wilkinson, G. Methods for age estimation and the study of senescence in bats. En H. Kunz \& S. Parsons. (Segunda edición), editores, Ecological and Behavioral Methods for the Study of Bats. EEUU. Johns Hopkins University Press. 2009: 315-325

18. LABORATORY AG. Extraction of DNA from tissue: High salt method. En DNA extraction. UK: University of Liverpool. Fecha de consulta: 27 de febrero de 2017.Disponible: http://www.genomics.liv.ac.uk/animal/RESEARCH/ISOLATIO.PDF

19. Levett, P., Morey, R., Galloway, R., Turner, D., Steigerwalt, A., \& Mayer, L. (2005). Detection of pathogenic leptospires by real-time quantitative PCR. Journal of Medical Microbiology, 54(1), 45-49. doi:10.1099/jmm.0.45860-0. 
20. Mgode, G., Mbugi, H., Mhamphi, G., Ndanga, D., \& Nkwama, E. (2014). Seroprevalence of Leptospira infection in bats roosting in human settlements in Morogoro municipality in Tanzania. Tanzania Journal of Health Research, 16(1), 1-7. doi:10.4314/thrb.v16i1.4.

21. Hice, C. L., Bunnell, J. E., Montrueil, V., Watts, D. M., Vinetz, J. M., \& Tesh, R. B. (2000). Detection of pathogenic Leptospira spp. infections among mammals captured in the Perúvian Amazon basin region. The American Journal of Tropical Medicine and Hygiene, 63(5), 255-258. doi:10.4269/ajtmh.2000.63.255.

22. Matthias, M., Diaz, M., Campos, K., Calderon, M., Willig, M., Pacheco, V., \& Vinetz, J. (2005). Diversity of bat-associated Leptospira in the Peruvian Amazon inferred by bayesian phylogenetic analysis of $16 \mathrm{~S}$ ribosomal DNA sequences. The American Journal of Tropical Medicine and Hygiene, 73(5), 964-974.

23. Franco Bessa, T. A., Spichler, A., Berardis Chapola, E. G., Husch, A. C., Fernandes de Almeida, M., Sodre, M. M., \& Vinetz, J. M. (2010). The contribution of bats to leptospirosis transmission in Sao Paulo City, Brazil. The American Journal of Tropical Medicine and Hygiene, 82(2), 315-317. doi:10.4269/ajtmh.2010.09-0227.

24. Dietrich, M., Mühldorfer, K., Tortosa, P., \& Markotter, W. (2015). Leptospira and Bats: Story of an Emerging Friendship. PLoS Pathogens, 11(11), e1005176. doi:10.1371/journal.ppat.1005176.

25. Odun, E. Ecología. México D. F. (1984). Nueva editorial Interamericana. 638-640. 